\title{
Undergraduate medical education in general practice/family medicine throughout Europe - a descriptive study
}

Mette Brekke ${ }^{1 *}$, Francesco Carelli2,3, Natalia Zarbailov ${ }^{4}$, Givi Javashvili $^{5}$, Stefan Wilm ${ }^{6}$, Markku Timonen ${ }^{7}$ and Howard Tandeter ${ }^{8}$

\begin{abstract}
Background: It is increasingly becoming evident that a strong primary health care system is more likely to provide better population health, more equity in health throughout the population, and better use of economic resources, compared to systems that are oriented towards specialty care. Developing and maintaining a strong and sustainable primary health care requires that a substantial part of graduating doctors go into primary care. This in turn requires that general practice/family medicine (GP/FM) strongly influences the curricula in medical schools. In the present paper we aim at describing the extent of GP/FM teaching in medical schools throughout Europe, checking for the presence of GP/FM curricula and clinical teaching in GP offices.

Methods: A brief questionnaire was e-mailed to GP/FM or other professors at European medical universities.

Results: 259 out of 400 existing universities in 39 European countries responded to our questionnaire. Out of these, 35 (13.5\%) reported to have no GP/FM curriculum. These 35 medical faculties were located in 12 different European countries. In addition, 15 of the medical schools where a GP/FM curriculum did exist, reported that this curriculum did not include any clinical component $(n=5)$, or that the clinical part of the course was very brief - less than one week, mostly only a few hours $(n=10)$. In total, 50 universities $(19 \%)$ thus had no or a very brief GP/FM curriculum. These were mainly located in the Eastern or Southern European regions.
\end{abstract}

Conclusion: It is still possible to graduate from European medical universities without having been exposed to a GP/FM curriculum. The European Academy of Teachers in General Practice (EURACT) will launch efforts to change this situation.

Keywords: General practice/family medicine, Medical education, Undergraduate, Clinical curriculum, Europe

\section{Background}

General practice/family medicine (GP/FM) is the provision of first contact, person focused, ongoing care over time that meets the health-related needs of people, referring only patients with uncommon or serious conditions, and coordinating care when people receive services at other levels of the healthcare system [1]. Primary health care means GP/FM applied on a population level, and as a population strategy this requires the commitment of governments to develop and sustain such services. It is

\footnotetext{
* Correspondence: mette.brekke@medisin.uio.no

'Department of General Practice, Institute of Health and Society, University of Oslo, P.O. Box 1130, Blindern, 0318 Oslo, Norway

Full list of author information is available at the end of the article
}

increasingly becoming evident that a strong primary health care system is more likely to provide better population health, more equity in health throughout the population, and better use of economic resources, compared to systems that are oriented towards specialty care [2-4]. The World Health Organization (WHO) identified primary health care as central to the achievement of the goal "Health for All" already in 1978 [5], and thirty years later encouraged all countries to orient their health care systems towards a strengthened primary care [3].

To develop and maintain a strong and sustainable primary health care requires that a substantial part of graduating doctors go into primary care [3]. This in turn requires that GP/FM strongly influences the curricula in

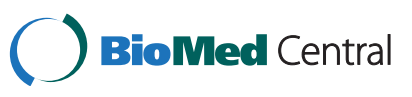


medical schools, although institutional, legislative and market factors also play important roles [6-8]. Specialty selection by medical students determines the future composition of the physician workforce. Among multiple reasons influencing a career choice either towards or away from primary care, medical school curricula may affect students in their perceptions of the role of primary care physicians. Since students are greatly influenced by the cultures of the institutions in which they are trained, the negative attitude of a university towards FM/GP may negatively affect the number of students going into this specialty [6]. Selection of career specialties begins in earnest during the clinical rotations with exposure to the clinical and intellectual environments of various specialties. A recent study from Israel found that as many as $62 \%$ of last year medical students considered choosing one specific specialty, while the rest considered two or more [9].

Still, however, undergraduate medical education seems to be out of synchrony with accelerating development and training in GP/FM [8]. In a former paper, our group developed a "minimal core curriculum" for undergraduate GP/ FM, meant as an aid for medical schools introducing the topic for the first time, usually starting with a very brief course [10]. Working in a GP/FM setting requires problem solving skills, that differ highly from the diseasecentered linear thinking inside university hospitals and which dominates the curricula in medical schools. In primary care the focus is upon the whole person - body and mind - in his/her context, and over long periods of time. Complex and poorly understood health problems, as well as clusters of diseases have to be handled, and the doctorpatient relationship is an important working tool. No student should graduate from medical school without substantial understanding of these matters $[8,10]$. In our opinion this requires - in addition to a theoretical GP/ FM curriculum - a substantial component of "masterapprentice" learning in a primary care clinic.

In the last decades many European countries have undergone dramatic changes, including democratization, economic liberalization and a redefinition of the role of the state. Health care and social services systems have been reformed, and new challenges have had to be faced $[4,11]$. In the present paper, we aim at assessing and describing the extent of GP/FM teaching in medical schools throughout Europe. Is there a GP/FM curriculum? And to which degree are the students able to participate in clinical work in a GP's office? Is it still possible to graduate as a doctor from a European university having learned nothing at all about GP/FM? We have not been able to find previous surveys on this matter.

\section{Methods}

The authors of this paper are national representatives in the Council of European Academy of Teachers in General
Practice and Family Medicine (EURACT) [12], and are members of EURACT's Basic Medical Education (BME) Committee. Following a brain-storm within the BME Committee items for a questionnaire were identified. To achieve the best possible response rate the questionnaire was made as brief and simple as possible (Table 1) and was accompanied by the following text: "The European Academy of Teachers in General Practice/Family Medicine (EURACT) is running a mapping of the presence of undergraduate FM/GP rotations/clerkships in all European Medical Schools. You are kindly requested to answer the attached short questionnaire about your own medical school". The questionnaire was sent by e-mail to GP/FM professors at each medical school in the countries of interest (where there were no GP/FM professors, the dean or another relevant professor was contacted). The authors divided the countries between them, and in several countries the national EURACT representative - not members of the BME-committee - aided in distributing the questionnaires and collecting the answers. Generally we accepted the data as they arrived from the respondents. The data collection took place in 2011 and until the end of 2012.

As the study did not collect data on human subjects, no approval from an ethics committee was needed.

\section{Results}

We were able to obtain information from 259 European medical schools in 39 countries (Tables 2, 3, 4 and 5). According to the "Avicenna Database" run by the University of Copenhagen in collaboration with World Federation for Medical Education (WFME), there are about 400 medical universities in these 39 European countries (http:/avicenna.ku.dk/database/medicine). Response rate was thus $64 \%$.

Out of the 259 respondent universities, 35 (13.5\%) reported to have no GP/FM curriculum (Table 6). These 35 medical faculties were located in eleven different European countries. In addition, 15 of the medical schools where a GP/FM curriculum did exist, reported that this curriculum

\begin{tabular}{l} 
Table 1 Questionnaire presented by The European \\
Academy of Teachers in General Practice/Family \\
Medicine (EURACT) \\
\hline Question \\
\hline Name of medical school \\
City \\
How many years is your medical program? \\
Does the school have a GP/FM curriculum? \\
If so, does it have a clinical component (student sits in with GP)? \\
What is the duration of this rotation in weeks? \\
During which year is the rotation presented? \\
Do you have such rotations in more than one year?
\end{tabular}


Table 2 Western Europe - state of GP/FM curriculum in medical schools

\begin{tabular}{lcll}
\hline Country $(n=5)$ & GP curriculum & \multicolumn{2}{c}{ Clinical component } \\
\cline { 3 - 4 } Medical school $(n=53)$ & Yes $/$ no & Weeks $n$ Which year
\end{tabular}

Austria

Medical University Graz

Medical University

Innsbruck

Medical University

Vienna

Medical University

Salzburg

Belgium

K.U. Leuven

Univ Gent

VUB Brussels

UA Antwerp

UCL Brussels

ULB Brussels

ULG Liege

Netherlands

Maastricht

Germany

Univ. Aachen

Berlin

Bochum

Bonn

Dresden

Düsseldorf

Erlangen

Essen

Frankfurt

Freiburg

Giessen

Göttingen

Greifswald

Halle

Hamburg

Hannover

Heidelberg

Homburg

Jena

Kiel

Köln

Leipzig

Lübeck

Magdeburg

$\begin{array}{ccc}\text { Yes } & 5 & 6^{\text {th }} \\ \text { Yes } & 4 & 6^{\text {th }} \\ \text { Yes } & 3 & 5^{\text {th }}+6^{\text {th }} \\ \text { Yes } & 4 & 5^{\text {th }}\end{array}$

Yes

Yes

Yes

Yes

Yes

Yes

Yes

Yes

Yes

Yes

Yes

Yes

Yes

Yes

Yes

Yes

Yes

Yes

Yes

Yes

Yes

Yes

Yes

Yes

Yes

Yes

Yes

Yes

Yes

Yes

Yes

Yes
Table 2 Western Europe - state of GP/FM curriculum in medical schools (Continued)

\begin{tabular}{lccc}
\hline Mainz & Yes & 1 & $5^{\text {th }}$ \\
Mannheim & Yes & $\begin{array}{c}\text { No } \\
\text { information }\end{array}$ \\
Marburg & Yes & 2 & $5^{\text {th }}$ \\
München (LMU) & Yes & 1 & $4^{\text {th }}$ \\
München (TU) & Yes & 2 & $4^{\text {th }}+5^{\text {th }}$ \\
Münster & Yes & 2 & $4^{\text {th }}$ \\
Regensburg & Yes & $?$ & \\
Rostock & Yes & 1 & $5^{\text {th }}$ \\
Tübingen & Yes & 2 & $5^{\text {th }}$ \\
Ulm & Yes & 2 & $4^{\text {th }}+5^{\text {th }}$ \\
Witten/Herdecke & Yes & $8-10$ & $1^{\text {st }}$ to $5^{\text {th }}$ \\
Würzburg & Yes & 5 & $5^{\text {th }}$ \\
Switzerland & & & $4^{\text {th }}$ \\
Univ of Basel & Yes & 4 & $1^{\text {st }}, 2^{\text {nd }}, 3^{\text {rd }}$ \\
Univ of Bern & Yes & 6 & $4^{\text {th }}, 6^{\text {th }}$ \\
Univ of Geneva & & & $2^{\text {nd }}, 4^{\text {th }}, 5^{\text {th }}$ \\
Univ of Lausanne & Yes & 3 & $3^{\text {rd }}, 4^{\text {th }}, 5^{\text {th }}, 6^{\text {th }}$ \\
Univ of Zürich & Yes & 5 & $3^{\text {rd }}, 4^{\text {th }}, 5^{\text {th }}$ \\
\hline
\end{tabular}

did not include any clinical component $(\mathrm{n}=5)$, or that the clinical part of the course was very brief - less than one week, mostly only a few hours $(n=10$, Table 6$)$. In total, 50 universities (19\%) thus had no or a very brief GP/FM curriculum.

Tables 2, 3, 4 and 5 show details of the GP/FM curriculum in the medical schools in the four European regions (according to the United Nations' Geo scheme and also including Israel). Roughly, the comprehensiveness of the GP/FM curriculum varies between the regions, as all faculties without any such curriculum are located either in Eastern or in Southern Europe, as are also the majority of schools without or with a very short clinical GP/FM component. Only few medical schools in Eastern Europe have a rotation period longer than two weeks, while the majority of schools in Northern Europe have at least five weeks, and several up to $12-13$ weeks.

There are substantial variations in length of the clinical component within countries and even inside the same city: for example the time spent in a GP's office is two weeks in one Brussels medical school and 12 weeks in another.

\section{Discussion}

One limitation of this study is that by labelling curricula as including or not including GP/FM, we assume the curricula to be mainly discipline based. We thus may have overlooked that a problem based or case based curriculum could include elements from GP/FM without 
Table 3 Eastern Europe - state of GP/FM curriculum in medical schools

\begin{tabular}{lcl}
\hline Country $(n=10)$ & GP curriculum & Clinical component \\
Medical school $(n=50)$ & Yes/No & Weeks Which year
\end{tabular}

Belarus

Minsk State Medical University ${ }^{1}$

No

Vitebsk State Medical University ${ }^{1}$

Gomel State Medical University ${ }^{1}$

GrodNo State Medical University ${ }^{1}$

Bulgaria

Medical University Plovdiv ${ }^{1}$

Medical University Sofia

Medical University Varna'

Medical University Pleven ${ }^{1}$

Medical faculty Stara Zagora ${ }^{1}$

Check Republic

Charles Univ in Prague,

first fac of med

Charles Univ in Prague,

second fac of med

Charles Univ in Prague,

third fac of med

Charles Univ, fac of med

Hradec Kralove ${ }^{2}$

Fac of med in Pilsen,

Masaryk University

Fac of med, Palacky

Univ Olomouc

Univ Ostrava, fac med

Georgia

Akaki Tsereteli State Univ,

Caucasus

International Univ Tbilisi ${ }^{1}$

David Agmashenelebi

Univ of Georgia

David Tvildiani Med Univ

Iv. Javakhishvili Tbilisi State Univ

Petre Shotadze Tbilisi Med Acad

Shota Rustaveli State Univ ${ }^{1}$

Tbilisi Med EduUniv Hippocrates

Tbilisi State Med Univ

Hungary

Semmelweis Univ Budapest

Univ of Szeged

Univ of Pecs

Moldova

Univ Nicolae Testemitanu

Chisinau
Table 3 Eastern Europe - state of GP/FM curriculum in medical schools (Continued)

\begin{tabular}{|c|c|c|c|}
\hline \multicolumn{4}{|l|}{ Poland } \\
\hline Med Univ of Bialystok ${ }^{2}$ & Yes & $2 \mathrm{~h}$ & $6^{\text {th }}$ \\
\hline Wroclaw Med Univ ${ }^{2}$ & Yes & $5 \mathrm{~h}$ & $6^{\text {th }}$ \\
\hline Med Univ of Gdansk & Yes & 2.5 & $6^{\text {th }}$ \\
\hline $\begin{array}{l}\text { Med Univ of Silesia, } \\
\text { School of Med in Katowice }\end{array}$ & Yes & 6 & $6^{\text {th }}$ \\
\hline Med Univ of Lodz & Yes & 4 & $5^{\text {th }}$ \\
\hline Med Univ of Lublin & Yes & 2.5 & $6^{\text {th }}$ \\
\hline Poznan Univ of Med Sciences ${ }^{2}$ & Yes & $<1$ & $6^{\text {th }}$ \\
\hline Pomorski Univ of Med Stettin & Yes & 2.5 & $6^{\text {th }}$ \\
\hline Med Univ of Warsaw & Yes & 2.5 & $6^{\text {th }}$ \\
\hline $\begin{array}{l}\text { Ludwig Rydygier CollMed } \\
\text { Bydgoszcz }\end{array}$ & Yes & 2 & $6^{\text {th }}$ \\
\hline \multicolumn{4}{|l|}{ Romania } \\
\hline Gr. T. Popa, Univ of Med, Lasi & Yes & 6 & $6^{\text {th }}$ \\
\hline Fac de Med Victor Papilian, Sibiu' & No & & \\
\hline Univ Transilvaia, Brasov² & Yes & No & \\
\hline $\begin{array}{l}\text { Univ Med Pharm, } \\
\text { Victor Babes, Timisoara }^{2}\end{array}$ & Yes & No & \\
\hline $\begin{array}{l}\text { Univ Med Pharm } \\
\text { Iuliu Hatieganu, Cluj-Napoca }\end{array}$ & Yes & 2.5 & $6^{\text {th }}$ \\
\hline \multicolumn{4}{|l|}{ Russia } \\
\hline KrasNoyarsk $^{2}$ & Yes & $30 \mathrm{~h}$ & $6^{\text {th }}$ \\
\hline State Med Univ Vladivostok & Yes & 1.5 & $6^{\text {th }}$ \\
\hline $\begin{array}{l}\text { Amurskaya State } \\
\text { Med Acad Blagoveshensk }\end{array}$ & Yes & 1 & $6^{\text {th }}$ \\
\hline State Med Univ Kursk ${ }^{2}$ & Yes & $6 \mathrm{~h}$ & $6^{\text {th }}$ \\
\hline State Med Univ Petrozavodsk ${ }^{2}$ & Yes & $6 \mathrm{~h}$ & $6^{\text {th }}$ \\
\hline $\begin{array}{l}\text { Pavlov's St.Petersburg } \\
\text { State Med Univ }\end{array}$ & Yes & 4 & $5^{\text {th }}, 6^{\text {th }}$ \\
\hline $\begin{array}{l}\text { State North-West Med Univ } \\
\text { St. Petersburg }\end{array}$ & Yes & 2 & $6^{\text {th }}$ \\
\hline \multicolumn{4}{|l|}{ Slovakia } \\
\hline Pavol Josef Safarik Univ Kosice & Yes & 1 & $4^{\text {th }}$ \\
\hline Jessenius Fac Med Martin & Yes & 2 & $5^{\text {th }}$ \\
\hline Comenius Univ Bratislava & No & & \\
\hline
\end{tabular}

having a proper GP/FM section. We also are aware of the fact that the mere existence of a GP/FM curriculum is not synonymous with high quality teaching. A further limitation is that we were not able to obtain data at all from some countries: Ukraine, Lithuania and France. These countries are "white spots on our map", although we have got information from a key informant in France that all Universities have incorporated FM/GP in their BME curriculum and that all of them have a clinical component (2-6 weeks). This information is in line with 
Table 4 Northern Europe - state of GP/FM curriculum in medical schools

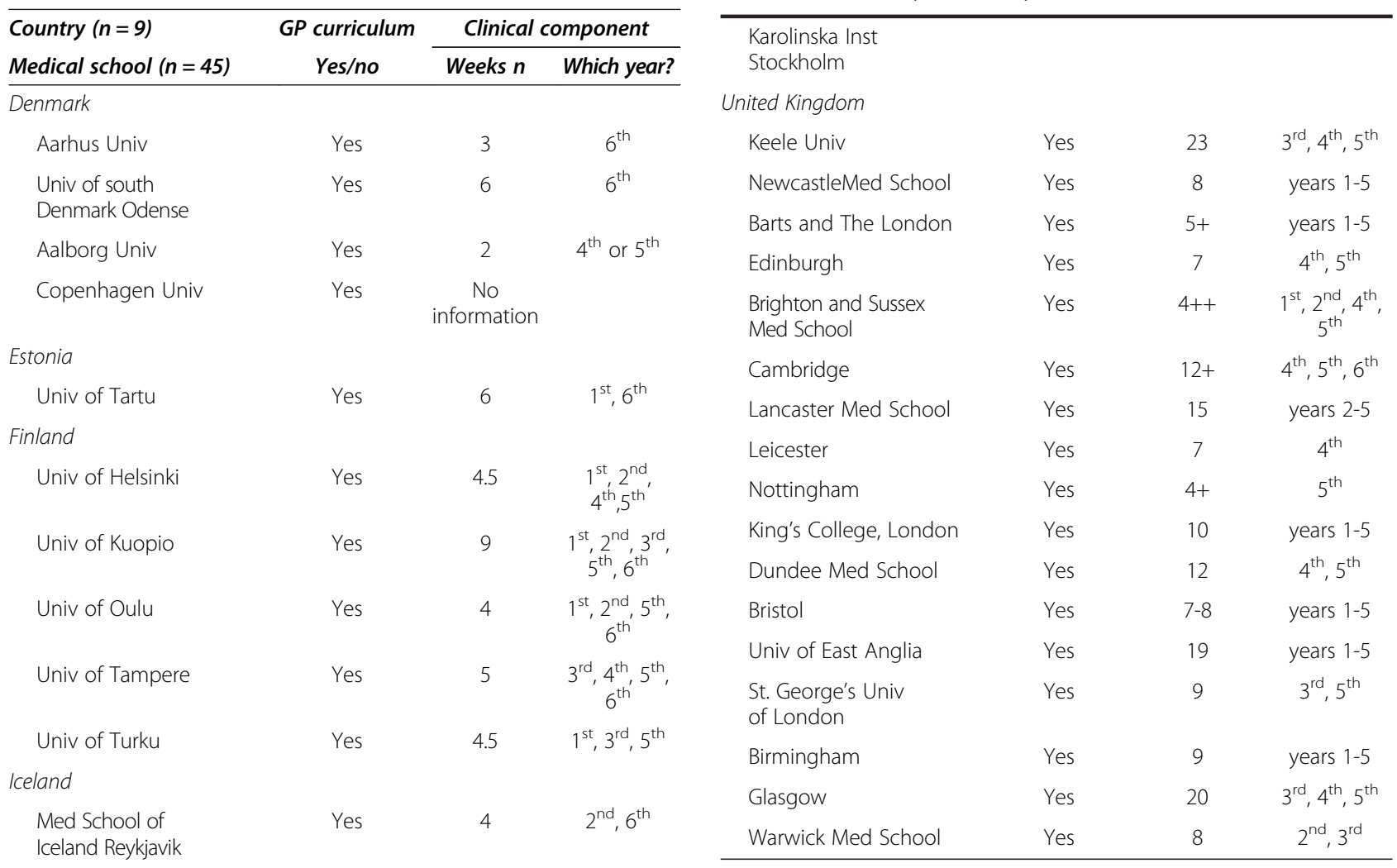

Ireland

Univ of Limerick

Royal College of

Surgeons Med School

Queens Univ Belfast

Trinity College, Dublin

NUI Galway

Univ College Cork

Latvia

Riga Stradins Univ

Univ of Latvia

Norway

Univ of Bergen

Univ of Oslo

Univ of Tromsø

Norw Univ of Science and Technol, Trondheim

sweden

Sahlgrenska Acedemy

Gothenburg

Linköping Univ

Örebro univ

Umeå Univ

$\begin{array}{llc}\text { Yes } & ? & 1^{\text {st }}, 4^{\text {th }} \\ \text { Yes } & 3 & 1^{\text {st }}, 4^{\text {th }} \\ \text { Yes } & 4 & 4^{\text {th }} \\ \text { Yes } & 4 & 4^{\text {th }} \\ \text { Yes } & 6 & 1^{\text {st }}, 2^{\text {nd }}, 4^{\text {th }} \\ \text { Yes } & 7 & 3^{\text {rd }}, 5^{\text {th }} \\ \text { Yes } & 4 & 6^{\text {th }} \\ \text { Yes } & 4 & 6^{\text {th }} \\ \text { Yes } & 4 & 6^{\text {th }} \\ \text { Yes } & 7 & 1^{\text {st }}, 2^{\text {nd }}, 5^{\text {th }} \\ \text { Yes } & 8 & 1^{\text {st }}, 5^{\text {th }} \\ \text { Yes } & 7 & 1^{\text {st }}, 2^{\text {nd }}, 6^{\text {th }} \\ \text { Yes } & 13 & \begin{array}{l}\text { years } 1-6 \\ \text { Yes }\end{array} \\ \text { Yes } & 6 & 1^{\text {st }}, 2^{\text {nd }}, 3^{\text {rd }}, \\ \text { Yes } & 12 & 5^{\text {th }} \\ \text { years } 1-6 \\ \text { years } 1-6\end{array}$

Table 4 Northern Europe - state of GP/FM curriculum in medical schools (Continued)

the rest of Western European universities, as all of them have GP/FM training with a clinical component. Also, not all universities have responded from each country. For example, we got data only from seven universities in Russia, while the number of medical schools in this country is more than 60 . Similarly, for Turkey we have data from 29 universities out of more than 50. Therefore, we cannot provide statistically valid information on the situation in Europe as such. On the other hand, the information that we do have from 259 European medical schools, in itself brings new insights, although curricula are in constant evolution and data captured at a certain point of time will not reflect such a dynamic situation.

In 2010 an independent international commission published a report on the need of transforming medical education in the future [13]. The commission states that professional education has not kept pace with the needs of patients and populations, and that fragmented and outdated curricula produce ill-equipped graduates. Reforms are therefore needed, and a list of ten proposed reforms is given. Point number eight states the need for medical schools to achieve: "Expansion from academic centers to academic systems, extending.......into primary care settings and communities..." [13]. It is thus positive that the majority of medical schools throughout the European regions do have a substantial GP/FM curriculum - 209 out 
Table 5 Southern Europe - state of GP/FM curriculum in medical schools

\begin{tabular}{lcrr}
\hline Country $(n=15)$ & GP curriculum & \multicolumn{2}{c}{ Clinical component } \\
\cline { 3 - 3 } Medical school $(n=107)$ & Yes/No & Weeks $n$ & $\begin{array}{l}\text { Which } \\
\text { year? }\end{array}$ \\
\hline
\end{tabular}

Albania

Univ of Tirana'

Bosnia-Herzegovina

Med fak Banja Luka

Med fak Tuzla

Croatia

Rijeka

Zagreb

Osijek

Split

Cyprus

Univ of Nicosia ${ }^{1}$ (only first two years of med school)

Greece

Athens $^{1}$
Aristotle Univ of
Thessaloniki
Patras $^{1}$
Heraklion, Crete
loannina
Alexandroupoli
Larissa
Italy

Univ of L'Aquila

Fac La Sapienza Yes

Fac di Med et Psicol Roma ${ }^{2} \quad$ Yes

Campus Biomedico Roma Yes

Univ of Udine

Univ of Trieste ${ }^{1}$

Central Milan

S.Paolo Milan

Vialba Milan

S.Donato Milan

Univ of GeNoa

Univ of Bari et Foggia

Macedonia

Univ SS Cyril \&

Methodius Skopje

State Univ Tetovo ${ }^{2}$

Univ Goce Delcev Stip ${ }^{2}$

Malta

Univ of Malta
No

year?

$\begin{array}{cl}\text { No } & 5^{\text {th }} \\ \text { information } & \\ 2 & 6^{\text {th }} \\ 2 & 6^{\text {th }} \\ 2 & 6^{\text {th }} \\ 2 & 6^{\text {th }}\end{array}$

No

No

Yes

No

Yes

Yes

No

No

Yes

Yes

Yes

Yes

Yes

No

Yes

Yes

Yes

Yes

Yes

Yes

Yes

Yes

Yes

$\begin{array}{ll}15 h & 6^{\text {th }} \\ 15 h & 6^{\text {th }}\end{array}$

Yes
Table 5 Southern Europe - state of GP/FM curriculum in medical schools (Continued)

\begin{tabular}{|c|c|c|c|}
\hline \multicolumn{4}{|l|}{ Montenegro } \\
\hline Podgorica & Yes & 1 & $4^{\text {th }}, 5^{\text {th }}$ \\
\hline \multicolumn{4}{|l|}{ Portugal } \\
\hline Univ da Coimbra & Yes & 10 & $6^{\text {th }}$ \\
\hline Univ da Lisboa & Yes & 10 & $\begin{array}{l}1^{\text {sr }}, 2^{\text {nd }} \\
6^{\text {th }}\end{array}$ \\
\hline Univ da Porto & Yes & 4 & $6^{\text {th }}$ \\
\hline Univ da Beira Interior & Yes & 4 & $\begin{array}{l}1^{\text {sr }}, 2^{\text {nd }}, 4^{\text {th }} \\
5^{\text {th }}, 6^{\text {th }}\end{array}$ \\
\hline Univ da Minho & Yes & 16 & $5^{\text {th }}, 6^{\text {th }}$ \\
\hline Univ da Algarve & Yes & 16 & $\begin{array}{l}1^{\text {st }}, 2^{\text {nd }} \\
3^{\text {rd }}\end{array}$ \\
\hline
\end{tabular}

Serbia

Med Fak Nis Yes

Med Fak Belgrade

Med Fak Kragujevac ${ }^{1}$

Med Fak Novi Sad ${ }^{1}$

Relocated Med Fak

from Pristina ${ }^{1}$

Slovenia

Ljubljana

Spain

Cadiz

Cordoba $^{2}$

Granada $^{2}$

Sevilla

Zaragoza

Asturias $^{2}$

La Laguna

Las Palmas

Cantabria

Salamanca

Valladolid

Albacete

UAB-Univ

AutoNoma Barcelona

Univ Barcelona

Girona

Lleida

Rovira I Virgili

Extremadura

Santiago

Univ AutoNoma de Madrid

Complutense de Madrid

Europ Univ Madrid
Yes

Yes

No

No

No

Yes

Yes

Yes

Yes

Yes

Yes

Yes

Yes

Yes

Yes

Yes

Yes

Yes

Yes

Yes

Yes

Yes

Yes

Yes

Yes

Yes

Yes $5^{\text {th }}$

$6^{\text {th }}$

$6^{\text {th }}$

4

No

No

$6^{\text {th }}$

$6^{\text {th }}$

$5^{\text {th }}, 6^{\text {th }}$

$6^{\text {th }}$

$6^{\text {th }}$

$3^{\text {rd }}, 6^{\text {th }}$

$6^{\text {th }}$

$1^{\text {st }}$

$5^{\text {th }}$

$3^{\text {rd }}, 4^{\text {th }}, 5^{\text {th }}$

$6^{\text {th }}$

$6^{\text {th }}$

$3^{\text {rd }}$

$6^{\text {th }}$

$5^{\text {th }}$ or $6^{\text {th }}$

No

information 
Table 5 Southern Europe - state of GP/FM curriculum in medical schools (Continued)

\begin{tabular}{|c|c|c|c|}
\hline Alfonso & Yes & 2 & \\
\hline Murcia & Yes & 4 & $6^{\text {th }}$ \\
\hline Navarra & Yes & 4 & $6^{\text {th }}$ \\
\hline Valencia & Yes & 1 & $3^{\text {rd }}$ \\
\hline Catholic Univ Valencia & Yes & 4 & $3^{\text {rd }}, 4^{\text {th }}$ \\
\hline Miguel Hernandez, San Juan & Yes & 6 & \\
\hline Pais Vasco & Yes & 2 & $6^{\text {th }}$ \\
\hline \multicolumn{4}{|l|}{ Turkey } \\
\hline Acibadem Istanbul & Yes & 13 & $\begin{array}{l}1^{\text {st }}, 2^{\text {nd }}, 3^{\text {rd }}, \\
6^{\text {th }}\end{array}$ \\
\hline Cukorova Adana & Yes & 3 & $6^{\text {th }}$ \\
\hline Kocatepe Afyon ${ }^{1}$ & No & & \\
\hline Ondokuzmayis Samsun & Yes & 4 & $6^{\text {th }}$ \\
\hline Osmangazi Eskisehir ${ }^{1}$ & No & & \\
\hline Selcuk Meram Konya ${ }^{1}$ & No & & \\
\hline $\begin{array}{l}\text { Sutcu Imam } \\
\text { Kahramanmaras }\end{array}$ & Yes & 4 & $6^{\text {th }}$ \\
\hline Trakya Edirne & Yes & 2 & $4^{\text {th }}$ \\
\hline Uludag Bursa & Yes & 1 & $6^{\text {th }}$ \\
\hline Tayfur Ata SokmenHatay & Yes & 4 & $6^{\text {th }}$ \\
\hline Bozok Yozgat $^{1}$ & No & & \\
\hline $\begin{array}{l}\text { Gulhane Askeri } \\
\text { Tip Akademisi }\end{array}$ & No & & \\
\hline \multicolumn{4}{|l|}{ Ankara $^{1}$} \\
\hline Ankara Univ & Yes & 1 & $5^{\text {th }}$ \\
\hline INonu Malatya & Yes & 4 & $6^{\text {th }}$ \\
\hline Marmara & Yes & 8 & $3^{\text {rd }}, 5^{\text {th }}, 6^{\text {th }}$ \\
\hline Pamukkale Denizli ${ }^{1}$ & No & & \\
\hline Mersin ${ }^{1}$ & No & & \\
\hline Dokuz Eylül Izmir ${ }^{1}$ & No & & \\
\hline Onsekiz Mart Canakkale & Yes & 8 (elective) & $5^{\text {th }}, 6^{\text {th }}$ \\
\hline Yeditepe Istanbul & Yes & 6 & $6^{\text {th }}$ \\
\hline Adnan Menderes Aydin & Yes & 5 & $5^{\text {th }}, 6^{\text {th }}$ \\
\hline Akdeniz Antalya & Yes & 5 & $3^{\text {rd }}, 6^{\text {th }}$ \\
\hline Baskent Ankara & Yes & 2 & $4^{\text {th }}$ \\
\hline Izzet Baysal Abant ${ }^{1}$ & No & & \\
\hline $\begin{array}{l}\text { Karadeniz Techn } \\
\text { Univ Trabzon }{ }^{1}\end{array}$ & No & & \\
\hline \multicolumn{4}{|l|}{ Trabzon ${ }^{1}$} \\
\hline Celal Bayar Manisa & No & & \\
\hline Yildirim Beyazit Ankara & Yes & 4 & $6^{\text {th }}$ \\
\hline Capa Istanbul' & No & & \\
\hline Gazi Osman Pasa Tokat & Yes & 4 & $5^{\text {th }}$ \\
\hline
\end{tabular}

Table 5 Southern Europe - state of GP/FM curriculum in medical schools (Continued)

\begin{tabular}{llll}
\hline Israel & & & \\
$\begin{array}{l}\text { Ben -Gurion Univ } \\
\text { Beer-Sheva }\end{array}$ & Yes & 6 & $6^{\text {th }}$ \\
Hebrew Univ Jerusalem & Yes & 2 & $6^{\text {th }}$ \\
$\begin{array}{l}\text { Tel-Aviv Univ } \\
\text { (6 y med school) }\end{array}$ & Yes & 4 & $6^{\text {th }}$ \\
$\begin{array}{l}\text { Tel-Aviv Univ } \\
\text { (4 y med school) }\end{array}$ & Yes & 3 & $4^{\text {th }}$ \\
Technion Haifa & Yes & 6 & $6^{\text {th }}$ \\
\hline
\end{tabular}

${ }^{1}$ No GP/FM curriculum $(n=22)$.

${ }^{2}$ No or $<1$ week clinical component $(n=6)$.

of the 259 faculties assessed. Even so, there is ample room and need for improvements, as 35 schools have no GP/ FM teaching whatsoever and clinical teaching is absent or very brief in several others.

Most former communist countries now let GP/FM play a key role in their health care system. A GP/FM curriculum is also increasingly being introduced into medical training at undergraduate and postgraduate level, and GP/FM is developed as an academic discipline $[11,14]$. Our study revealed that this task can not yet be seen as completed. It is especially worrying if it is possible both to graduate without any GP/FM competence and subsequetly set up a practice in a country without a mandatory vocational training program.

European primary care is currently facing high expectactations, regarding its promises to improve population health, control costs, and attribute to less socioeconomic inequality of care [1-4]. But: Do strong primary care systems indeed perform better? And what determines how strong primary care is? [15]. These important questions have recently been addressed by means of a EU-funded project: the Primary Health Care Activity Monitor for Europe (PHAMEU) [16]. Based on information from 31 European countries the study was able to show that strong primary care indeed was associated with better population health outcomes, lower rates of potentially avoidable hospitalization, lower socioeconomic inequality in self-rated health, a reduced growth of health care spending, but also with higher levels of total health care costs [17]. In total, this should support the efforts of policy makers to prioritize primary care. Development of primary care workforce is part of such efforts [18], and developing a comprehensive GP/FM undergraduate curriculum comprising a clinical rotation is a necessity in this process [6-8].

In our study most clinical GP/FM rotations were placed in years four, five or six, but as the length of the clinical teaching period increased, it is common to spread it over several semesters. For example the 1213 weeks of rotations at three Swedish universities involve the years one to six. This probably has a positive 
Table 6 Medical universities without GP/FM curriculum, or with clinical GP/FM teaching lacking or shorter than one week

\begin{tabular}{|c|c|}
\hline Country & Medical schools without GP/FM curriculum $(n=35)$ \\
\hline \multirow[t]{4}{*}{ Belarus } & Minsk State Medical University \\
\hline & Vitebsk State Medical University \\
\hline & Gomel State Medical University \\
\hline & Grodno State Medical University \\
\hline \multirow[t]{4}{*}{ Bulgaria } & Medical University Plovdiv \\
\hline & Medical University Varna \\
\hline & Medical University Pleven \\
\hline & Medical faculty Stara Zagora \\
\hline Chech Republic & Univ. Ostrava, fac med \\
\hline \multirow[t]{2}{*}{ Georgia } & International Univ Tbilisi \\
\hline & Shota Rustaveli State Univ \\
\hline Romania & Fac de Med Victor Papilian, Sibiu \\
\hline Slovakia & Comenius Univ Bratislava \\
\hline Albania & University of Tirana \\
\hline Cyprus & University of Nicosia (only first two years of med school) \\
\hline \multirow[t]{4}{*}{ Greece } & Athens \\
\hline & Patras \\
\hline & Alexandroupoli \\
\hline & Larissa \\
\hline Italy & University of Trieste \\
\hline \multirow[t]{3}{*}{ Serbia } & Med Fak Kragujevac \\
\hline & Med Fak Novi Sad \\
\hline & Relocated Med Fak from Pristina \\
\hline \multirow[t]{13}{*}{ Turkey } & Kocatepe Afyon \\
\hline & Osmangazi Eskisehir \\
\hline & Selcuk Meram Konya \\
\hline & Bozok Yozgat \\
\hline & Gulhane Askeri Tip Akademisi Ankara \\
\hline & Pamukkale Denizli \\
\hline & Mersin \\
\hline & Dokuz Eylül Izmir \\
\hline & Izzet Baysal Abant \\
\hline & Karadeniz Techn Univ Trabzon \\
\hline & Celal Bayar Manisa \\
\hline & Capa Istanbul \\
\hline & $\begin{array}{l}\text { Medical schools with no or }<1 \text { week clinical } \\
\text { teaching }(n=15)\end{array}$ \\
\hline Chech Republic & Charles Univ, fac of med Hradec Kralove \\
\hline \multirow[t]{3}{*}{ Poland } & Med Univ of Bialystok \\
\hline & Wroclaw Med Univ \\
\hline & Poznan Univ of Med Sciences \\
\hline \multirow[t]{2}{*}{ Romania } & Univ Transilvaia, Brasov \\
\hline & Univ Med Pharm, Victor Babes, Timisoara \\
\hline
\end{tabular}

Table 6 Medical universities without GP/FM curriculum, or with clinical GP/FM teaching lacking or shorter than one week (Continued)

\begin{tabular}{ll}
\hline Russia & Krasnoyarsk \\
& State Med Univ Kursk \\
& State Med Univ Petrozavodsk \\
Italy & Fac di Med et Psicol Roma \\
Macedonia & State Univ Tetovo \\
& Univ Goce Delcev Stip \\
Spain & Cordoba \\
& Granada \\
& Asturias
\end{tabular}

influence on recruitment to GP/FM, as students are exposed to role models throughout their entire education [6-8]. In our opinion GP/FM should be positioned as one of the main clinical topics in every European medical school, and teaching in a one-to-one situation in a GP's office should be offered for at least four weeks, preferably longer.

\section{Conclusion}

Although the majority of the assessed universities reported to have a theoretical GP/FM curriculum as well as a clinical rotation, it is still possible to graduate from some European medical schools without having learned about clinical work in a primary care setting. The European Academy of Teachers in General Practice (EURACT) will lance efforts to change this situation. Special efforts should be made in Eastern and Southern Europe, where a FM/GP curriculum does not exist in several universities, and where the clinical GP/FM component is generally short.

\section{Competing interests}

The authors declare that they have no competing interests.

Authors' contributions

The group of authors planned the study together, and all contributed to data collection. MB drafted the paper, with contribution from the group. All authors have given final approval of the version to be published.

\footnotetext{
Author details

${ }^{1}$ Department of General Practice, Institute of Health and Society, University of Oslo, P.O. Box 1130, Blindern, 0318 Oslo, Norway. ${ }^{2}$ University of Milan, Milan, Italy. ${ }^{3}$ University Campus BioMedico in Rome, Rome, Italy. ${ }^{4}$ Department of Family Medicine, State Medical and Pharmaceutical University "Nicolae Testemitanu", 165 bd. Stefan Cel Mare si Sfint, 2004 Chisinau, Moldova. ${ }^{5}$ Department of Family Medicine, Tbilisi State Medical University, 33 Vazha-Phshavela Avenue, Tbilisi 0177 Georgia. ${ }^{6}$ Institute of General Practice, Medical Faculty, Heinrich Heine University, Moorenstr. 5, 40225 Duesseldorf, Germany. ${ }^{7}$ Institute of Health Sciences, University of Oulu, P.O. Box 5000, FIN-90014 Oulu, Finland. ${ }^{8}$ Department of Family Medicine, Ben Gurion University, P.O. Box 653, 84105 Beer Sheva, Israel.
} 
References

1. Starfield B: Toward international primary care reform. CMAJ 2009, 180:1091.

2. Starfield B: Primary care: an increasingly important contributor to effectiveness, equity, and efficiency of health services. Gac Sanit 2012, 26:20-26.

3. World Health Organization 2008: The World Health Report 2008 - primary health care (now more than ever). [http://www.who.int/whr/2008/whr08_en.pdf] (06.10.2013).

4. Macinko J, Starfield B, Erinosho T: The impact of primary healthcare on population health in low- and middle-income countries. J Ambul Care Manage 2009, 32:150-171.

5. World Health Organization: Primary health care. Report of the international conference on primary health care. USSR: Alma Ata; 1978.

6. Tandeter H, Granek-Catarivas M: Choosing primary care? Influences of medical school curricula on career pathways. Isr Med Assoc J 2001, 3:969-972.

7. Henderson E, Berlin A, Fuller J: Attitude of medical students towards general practice and general practitioners. Br J Gen Pract 2002, 52:359-363.

8. Soler JK, Carelli F, Lionis C, Yaman H: The wind of change: After the European definition - orienting undergraduate medical education towards general practice/family medicine. Eur J Gen Pract 2007, 13:248-251.

9. Weissman C, Zisk-Rony RY, Schroeder JE, Weiss YG, Avidan A, Elchalal U, Tandeter $\mathrm{H}$ : Medical specialty considerations by medical students early in their clinical experience. Isr J Health Policy Res 2012, 1:13

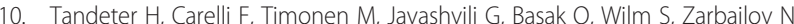
Spiegel W, Brekke M: A "minimal core curriculum" for Family Medicine in undergraduate medical education: a European Delphi survey among EURACT representatives. Eur J Gen Pract 2011, 17:217-220.

11. Rechel B, McKee M: Health reform in central and eastern Europe and the former Soviet Union. Lancet 2009, 374:1186-1195.

12. EURACT: European Academy of Teachers in General Practice/Family Medicine. http://www.euract.eu/ (27.11.2013).

13. Frenk J, Chen L, Bhutta ZA, et al: Health professionals for a new century: transforming education to strengthen health systems in an interdependent world. Lancet 2010, 376:1923-1958.

14. Krzton-Krolewiecka A, Svab I, Oleszczyk M, Seifert B, Smithson WH, Windak A: The development of academic family medicine in central and eastern Europe since 1990. BMC Fam Pract 2013, 14:37.

15. Stoffers J: The strength of primary care in Europe (editorial). Eur J Gen Pract 2013, 19:1-2

16. Project $N^{\circ} 2006130$ under EU Health Programme 2008-2013: Primary Healthcare Activiy Monitor for Europe. http://ec.europa.eu/eahc/projects/database/ database new.inc.data.2006130.pdf (27.11.2013).

17. Kringos DS, Boerma W, van der Zee J, Groenwegen P: Europe's strong primary care systems are linked to better population health but also to higher health care spending. Health Aff 2013, 32:686-694.

18. Kringos DS, Boerma WGW, Hutchinson A, van der Zee J, Groenwegen PP: The breadth of primary care: a systematic literature review of its core dimensions. BMC Health Serv Res 2010, 10:65.

doi:10.1186/1472-6920-13-157

Cite this article as: Brekke et al:: Undergraduate medical education in general practice/family medicine throughout Europe - a descriptive study. BMC Medical Education 2013 13:157.

\section{Submit your next manuscript to BioMed Central and take full advantage of:}

- Convenient online submission

- Thorough peer review

- No space constraints or color figure charges

- Immediate publication on acceptance

- Inclusion in PubMed, CAS, Scopus and Google Scholar

- Research which is freely available for redistribution

Submit your manuscript at www.biomedcentral.com/submit
C Biomed Central 